\title{
COLLECTION AND CURATION OF TRILLIUM SPECIES AT THE ROYAL BOTANIC GARDEN EDINBURGH
}

\author{
Robert Unwin ${ }^{l}$
}

\begin{abstract}
The genus Trillium are spring-flowering woodland plants which thrive at the Royal Botanic Garden Edinburgh. The rationale, planning and collection details of a field trip to the eastern states of the USA in 2011 are described. An account of the living and seed collections made of trilliums and associated species and their germination and establishment following the trip is given. A list of the species collected is provided as an appendix.
\end{abstract}

\section{INTRODUCTION}

In 2010, species in the genus Trillium (Liliaceae) in the Living Collection at the Royal Botanic Garden Edinburgh (RBGE) were audited. As a consequence, a field trip to increase the proportion of verified and wild collected species in this collection was undertaken in 2011. This paper describes the outcomes of the audit, the collections made and their subsequent germination and cultivation at the Edinburgh Garden of RBGE.

\section{TRILLIUM SPECIES AT THE ROYAL BOTANIC GARDEN EDINBURGH PRIOR TO 2010}

For many years RBGE has grown a large collection of trilliums, most of them planted in the Woodland Garden at Edinburgh. In 2010, Martin Gardner and Lesley Scott carried out an audit of the Living Collection and found that despite the genus being well represented in the collection, only a small percentage of these had been collected from the wild.

The 2006 Catalogue of Plants (Rae et al., 2006a) lists 13 different species of trillium in the Living Collection with several subspecies and varieties also listed. However, since then the Woodland Garden has been redeveloped and it was discovered that Trillium govanianum, T. tschonoskii and T. sessile were no longer alive.

Of the few that were of known wild origin, two species were collections made by Alfred Evans in the early 1980s. Evans was Assistant Curator at RBGE from December 1939 to May 1985. His collections of Trillium rivale and T. ovatum from the western states of the USA still thrive in the collection. Another North American species in the Collection, T. pusillum, was also of wild origin. The only other wild collected species

1. Robert Unwin is a Senior Horticulturist in the Alpine Department at the Royal Botanic Garden Edinburgh. Address: 20A Inverleith Row, Edinburgh, EH3 5LR, UK.

Email: R.Unwin@rbge.org.uk 
were two naturally occurring hybrids native to Japan, $T . \times$ hagae and, perhaps the most unspectacularly flowered of all trilliums, $T$. $\times$ miyabeanum.

\section{PLANNING THE COLLECTION TRIP}

It was with this in mind that Lesley Scott and I applied for funding to travel to the USA to collect trillium species. Targeted plant collection trips are favoured by both the RBGE Expedition Committee and external funding bodies. Collections such as these help RBGE to achieve its aim to increase the percentage of wild collected plants by 1 per cent a year (Rae et al., 2006b). Trilliums generally thrive and bulk up well in the growing conditions at Edinburgh; a combination of regular division, a favourable cool summer climate and the deep humus-rich soil of the Woodland Garden at RBGE suit most species very well. Added to this was the fact that trilliums are one of the most attractive woodland plants and are hugely enjoyed by the visitors to RBGE.

After making successful applications to the Royal Horticultural Society Bursary Fund, the Scottish Rock Garden Club Explorations Fund and the RBGE Expedition Committee, Lesley (who was then a Horticulturist in the Alpine Department at RBGE but has since moved to the Science Division as a Herbarium Technician) and I were in a position to firm up our plans to travel to the USA. Our trip was given the collectors' code acronym of USMWST.

It was decided to target species which grow in the eastern states of the USA; not only is this the centre of diversity for the genus Trillium but it was also the area for which our collection was most lacking in wild collected material. The Appalachian Mountains are home to many other interesting herbaceous and woody plants suitable for cultivation in Scotland, which further added to the appeal of collecting there. Our main point of contact was Rick Lewandowski, Director of Mt. Cuba Center, Delaware. Rick has a wealth of experience collecting plants, and particularly trilliums, in the eastern states for the Mt. Cuba garden, which specialises in growing native species from throughout the USA and has a wonderful collection of trilliums.

Living plants brought back to RBGE require the correct permits regarding their collection and importation and are placed in quarantine on arrival. Rick secured permission to collect, including a permit allowing us to collect seed and plants within the national parks we planned to visit. The RBGE Plant Pathologist, Stephan Helfer, issued a permit allowing the importation of live plant material from the USA to the UK. On arrival at the Garden, living plants were taken to the Quarantine House where they were inspected by the Plant Pathologist to determine the presence of any pests or disease. Each collection was then given an assessment on its likelihood of survival, expressed as a percentage. Plants in the Quarantine House are supervised and cared for in isolation for a minimum of three months in active growth when they are again inspected for pests and disease. When they are deemed to be absolutely clean they are released for planting out. 


\section{MAKING THE COLLECTIONS}

It was with Rick's recommendation that Lesley and I planned our trip to focus on the Appalachian Mountains and the city of Asheville, North Carolina. One of Rick's regular collaborators in this region is botanist Dr Larry Mellichamp from Charlotte University, NC. Larry has also written in this journal about a group of plants for which he is a respected expert: Sarracenia pitcher plants (Mellichamp, 2008). He kindly agreed to give up two weeks of his time to accompany Rick, Lesley and me on our trip, and with his local knowledge and botanical expertise he was another invaluable member of our team. Along the way we met up with several local botanists and keen amateur enthusiasts who accompanied us for several days at a time as we searched for plants of interest. The importance of local knowledge cannot be overstated on such trips; whether looking for plants in your own back yard or in faraway places, local knowledge is invaluable when collecting in the field.

It is safe to say that the process of germination in trilliums is not properly understood: "This genus is notorious for extended and difficult germination" (Case \& Case, 1997). Because of this, we sought permits to collect very small numbers of living plants as well as seed. On Rick's advice the timing of our trip was calculated to coincide with trillium seed production but with the intention to collect living material as well. This was as an insurance against poor germination and would also significantly reduce the time taken for our collections to be planted out in the Garden and appreciated by visitors. With the collection of seed it is possible to introduce a relatively large number of plants to cultivation because seed pods usually contain 15 to 50 seeds.

We departed for North Carolina in late July 2011 where we met up with Rick and Larry, arriving in temperatures well over $35^{\circ} \mathrm{C}$ and with humidity approaching $100 \%$. We soon acclimatised and headed off towards the city of Asheville, NC, near to the Appalachian Mountains where we planned to make most of our collections. The 469-mile-long Blue Ridge Parkway became our commuter route to work for the next three weeks. The Parkway was built to connect Shenandoah National Park to the Great Smoky Mountains National Park and although not strictly a National Park itself it is the most visited part of the National Park System in the USA.

It wasn't long before we encountered our first trillium. Bearing in mind that we were outside the flowering season for trilliums, there were none of the large eye-catching flowers to grab our attention. If it had not been for the local knowledge of our team I am sure it would have been several more days before Lesley and I had found any.

The genus Trillium is split into two subgenera: those which bear their flower on an extended pedicel, classified as 'pedicellate' trilliums in subgenus Trillium, and those which have no extension to the pedicel and whose flower develops at the point where the bracts are to be found. Scientifically, a structure attached without a stalk is referred to as sessile, hence these species are commonly referred to as 'sessile' trilliums, and are in the subgenus Phyllantherum. This difference in the botany of the two groups means that seed of sessile species such as T. erectum are easier to find (see Fig. 4). 


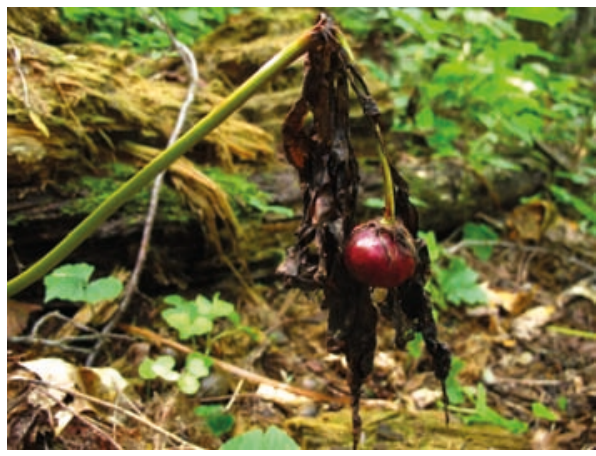

Fig. 1 The hidden ripe seed pod of Trillium vaseyi proved difficult to collect as the withered leaves camouflaged it well against the tapestry of the forest floor vegetation. Photo: Robert Unwin.

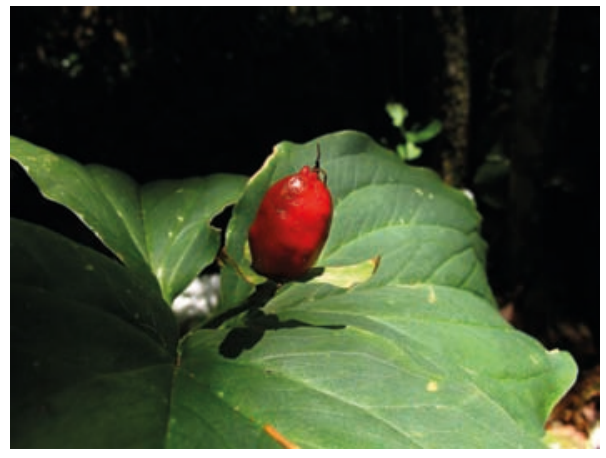

Fig. 2 The scarlet seed pod of Trillium undulatum easily caught the eye. Photo: Robert Unwin.

Pedicellate species include Trillium sulcatum, T. vaseyi (Fig. 1) and T. simile all of which initially hold their flowers above the leaves, making them attractive garden plants. On pollination and development of the seeds the pedicel droops below the leaves as the ovary ripens and matures. This makes the seed pod difficult to find in the undergrowth of the forest floor, especially as the leaves die off later in the season so they wither and yellow, hiding the seed pod further. An exception to this is T. undulatum which is also a pedicellate species, but in this species the seed pod ripens above the leaves and as it matures it becomes bright red, which makes it stand out and the seed collector's task much easier. It was the scarlet-red seed pods of T. undulatum (Fig. 2) which we discovered first, making it the first to be ticked off the 'wish list'.

Plants in the subgenus Phyllantherum have no extension to the pedicel and the flower develops at the point where the bracts are found. Most of the species in this subgenus hold their petals erect from the leaves and the ripening seed pod also develops in the same position above the leaves. On our field trip we only encountered two species in this sessile group. Sadly, when we found T. luteum we located only three or four seed pods as most had fallen from the plant where they had been rapidly dispersed by ants. Trillium seed has an elaiosome attached to the outer surface of the seed which has the purpose of attracting ants. The elaiosome is rich in lipids and proteins - a useful food source to the ant, which carries the seed off to its underground home to feed on the elaiosome, after which the undamaged seed is discarded and may germinate. We encountered the same with T. cuneatum. At one point we ventured into the state of Georgia where we found a small population, but all the seed pods had fallen to the ground and only a small number of seeds were present. Fortunately, on both occasions we were able to collect rhizomes to bring back with us.

On this trip I discovered the ideal tool for collecting trillium rhizomes (Fig. 3). Based on the design of the Hori-Hori, a Japanese gardening tool, the North American version of the soil knife has been a very useful addition to my plant collecting kit ever 


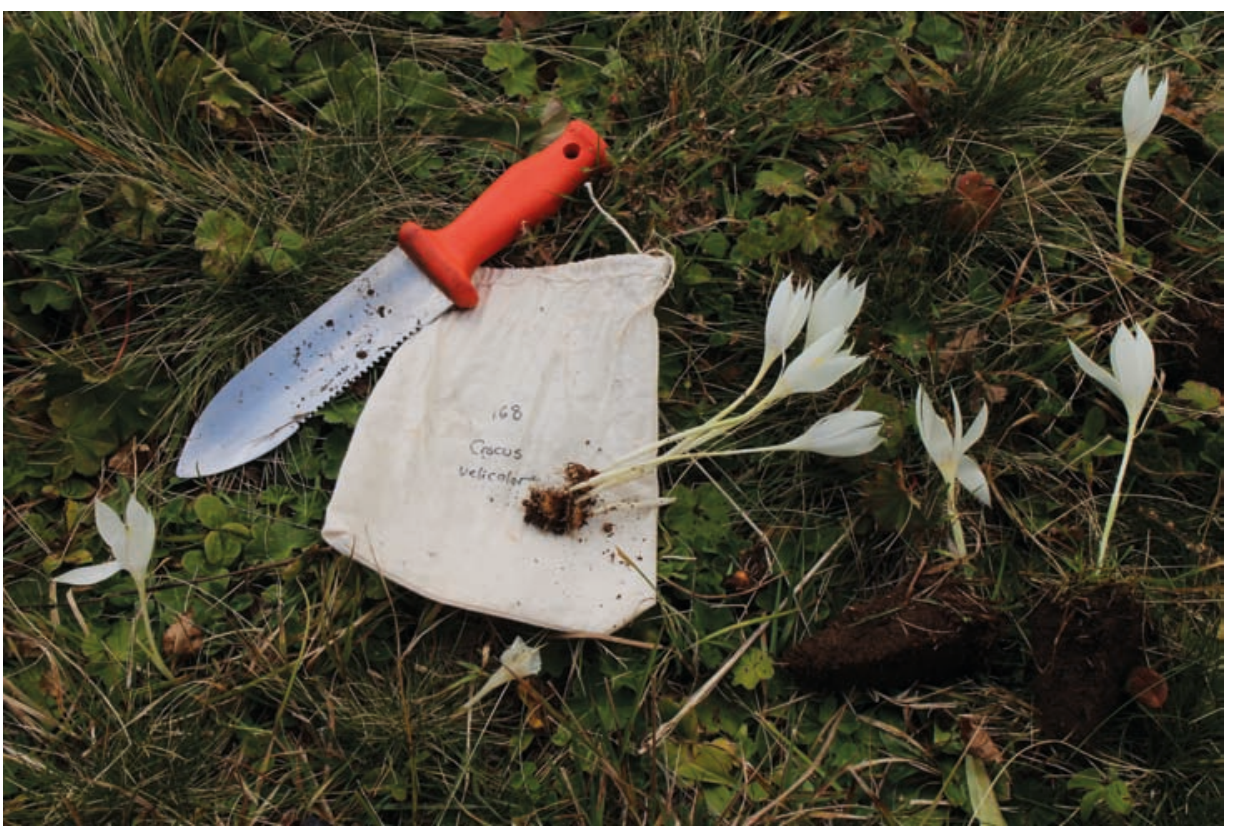

Fig. 3 The soil knife has proved to be an invaluable tool on a number of plant collection trips. Photo: Robert Unwin.

since. It is a similar size to a normal garden trowel and is very robust, with a stainless steel blade and moulded plastic handle. One side of the blade is serrated, making cutting through the fibrous roots of the surrounding vegetation very easy. This tool enables the collector to cut out a round plug of soil with the trillium rhizome in the centre, without the need to dig up the surrounding vegetation and without damaging the small rhizome.

Ten species of Trillium were collected on this trip: T. catesbaei, T. cuneatum, T. erectum, $T$. grandiflorum, $T$. luteum, $T$. rugelii, T. simile, $T$. sulcatum, $T$. undulatum and $T$. vaseyi. These species were represented by over 50 accessions, including living material and seed. All but T. erectum were not previously represented in the Living Collection as wild collected material.

\section{CARING FOR THE COLLECTIONS IN THE FIELD}

Care of the specimens once collected played an important part in their successful establishment at RBGE. Several of the seed pods were ripe but not quite ripe enough to naturally shed their seeds. Where this was the case we did not immediately clean them but kept them intact in a clearly labelled plastic self-sealing bag. Where possible all the seed was stored in the refrigerator of the motel room. Seed was inspected daily and when the pod showed signs of deteriorating all seeds were cleaned from the pod to prevent them from rotting. Trillium seed is reasonably large and fleshy, so after cleaning they 
were wrapped in very slightly moistened kitchen paper and placed in a self-sealing bag in the refrigerator again. This ensured that the seeds didn't desiccate. They were sown immediately on return to RBGE and the pots were placed in a cold frame outside where they would experience two winters before the first leaves appeared in spring 2013.

Maintaining the health of living collections on a trip with the extreme temperatures that can build up in the vehicle used is a challenge. The $4 \times 4$ hired for the journey was large enough to accommodate luggage and a large coolbox which was stocked with ice every day from motels or petrol stations. The living material was stored in the coolbox when travelling between motels. When a refrigerator was available, the plants were the first item to be unpacked from the vehicle and placed in the refrigerator. As much of the soil as practically possible was kept with the specimens until the last minute when all soil was washed off and the plants wrapped in moist kitchen paper for air travel to Scotland. The plants collected were treated as if they were dormant and any remaining green leaves were removed to reduce transpiration and moisture loss. Self-sealing bags were used and were invaluable for packaging these plants up in preparation for the return journey. They were packed into several large plastic containers in order to protect them. All living material was transported as hand luggage in order to eliminate the chance of it being lost on the journey home.

\section{ESTABLISHING THE COLLECTIONS}

Trilliums are slow growing. They take two years to produce visible signs of germination with a tiny leaf. Personal experience has taught me that a rhizome which is of flowering size can take anything from a further two or three years, in the case of $T$. rivale, to six or seven years for many other species to flower.

The seeds began to germinate in spring 2013 which was expected. Most plants raised from seed in the Alpine Department at RBGE are potted up into individual pots

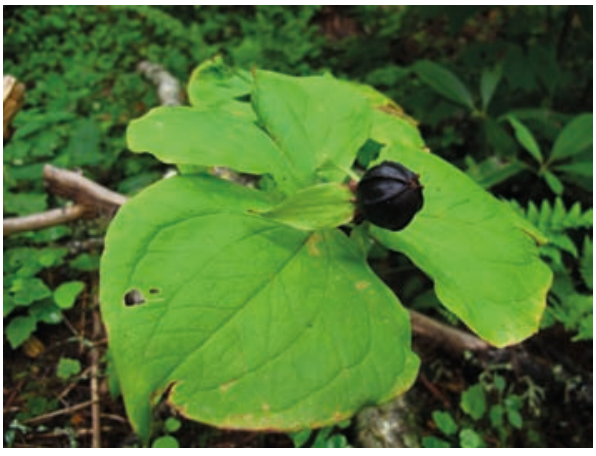

Fig. 4 A ripe seed pod of Trillium erectum growing on the woodland floor in North Carolina. Photo: Robert Unwin.

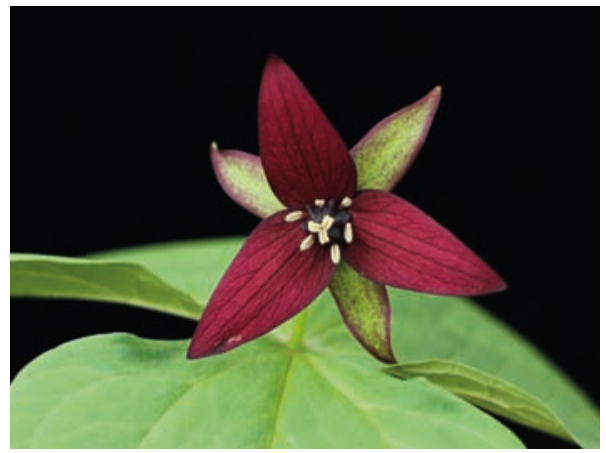

Fig. 5 The subsequent collection of living material, Trillium erectum 20111356, from North Carolina flowering in cultivation at RBGE in 2013. Photo: Robert Unwin. 
once they reach a suitable size. However due to their slow growth the trillium seedlings were treated differently. In June the pots of germinated seedlings were potted up as a clump from a $7 \mathrm{~cm}$ square plastic pot to a $9 \mathrm{~cm}$ pot to give the seedlings extra space but to avoid root disturbance. Throughout the season they were fed with a weak liquid feed to aid growth. In the coming years this process will probably be repeated several times before the rhizomes are of a suitable size to be treated as individuals. When they are big enough to be potted singly a nursery bed will be constructed in order to plant them out together and enable them to grow to a size suitable for planting in the public garden. Trilliums grow well not only at the Edinburgh Garden but at the other three Regional Gardens of RBGE so that in time plants will be distributed to Dawyck, Logan and Benmore Botanic Gardens.

\section{SURPRISE COLLECTIONS}

The story behind our collection of T. grandiflorum (Fig. 6) is slightly different from the other living collections. This species is second only to T. ovatum (from the western states of the USA) to flower at RBGE and it is an early flowering species in its native country too. This early flowering also results in early seed ripening and dormancy compared with other species in North Carolina and so, despite visiting known locations of T. grandiflorum, we failed to find any seed or plants - or so we thought. It wasn't until spring 2012, when the plants came into flower in the Quarantine House, that we realised we

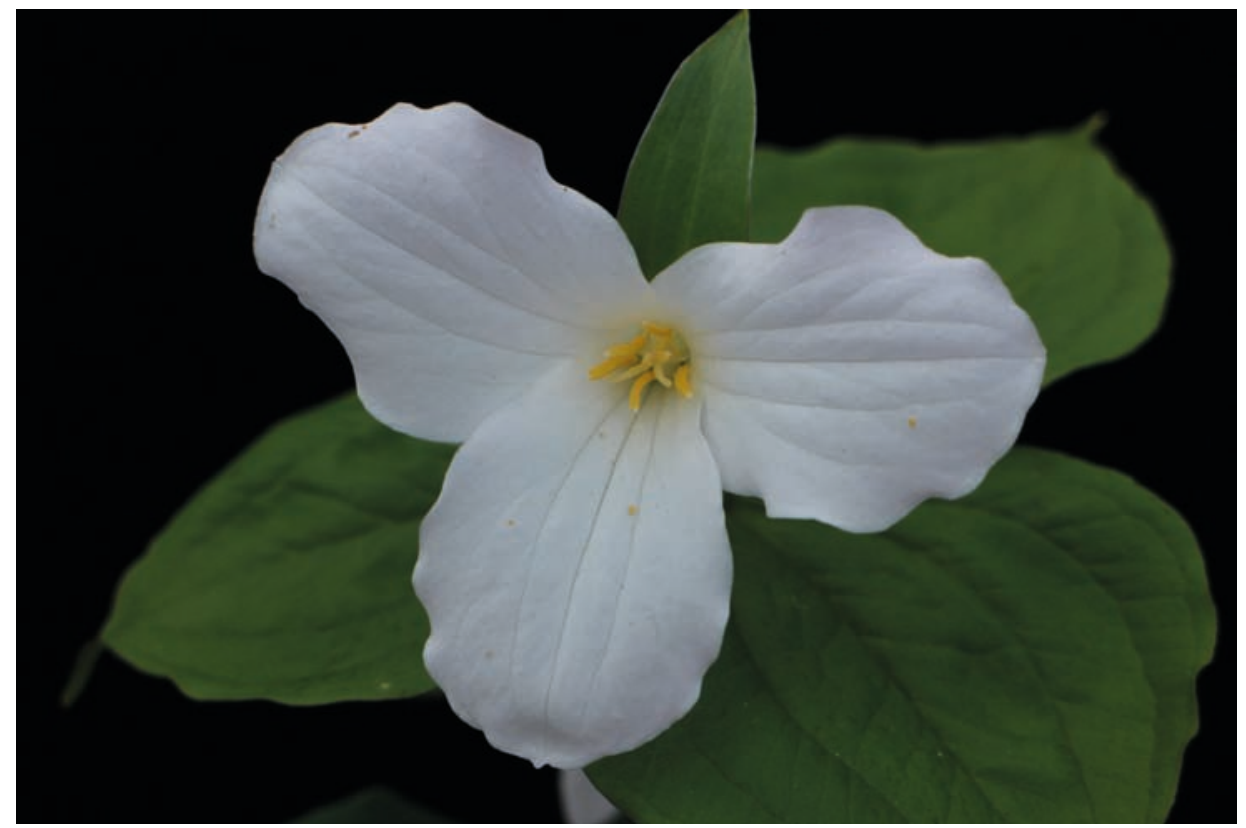

Fig. 6 Originally collected as Trillium erectum this rogue was clearly T. grandiflorum, now renamed and re-accessed as 20111313. Photo: Robert Unwin. 
had actually collected it on several occasions because rogue $T$. grandiflorum plants were observed in several pots labelled as other species. These plants were clearly marked and carefully removed from the pots, renamed and re-accessed. These plants retain all the collection data of the plant they were mistaken for but represent an additional and unexpected collection from the trip. This highlights the problem of collecting this group at this time of year. Although factors such as the leaf characteristics, seed pod characteristics, habitat, associated species and previous records for the site were taken into account when identifying the species, when they are not in flower it is particularly difficult to distinguish between some species. T. rugelii and $T$. vaseyi are particularly easily confused.

The living collections that were made, with one exception (a collection of $T$. undulatum which seems not to have broken dormancy yet), have been released from quarantine at the time of writing in June 2014. I have found that trilliums are happier in the open ground than growing in pots and so they were planted as quickly as was suitable in the Lower Woodland area of the Garden. Each specimen had from four to ten rhizomes which were put into a single pot in the Quarantine House after inspection. When these plants left quarantine they were in active growth and it was thought best not to disturb the roots but to simply plant them as one. Throughout the summer season they were monitored and just prior to entering dormancy were carefully lifted and teased apart to separate the rhizomes. They were replanted in the same location with additional

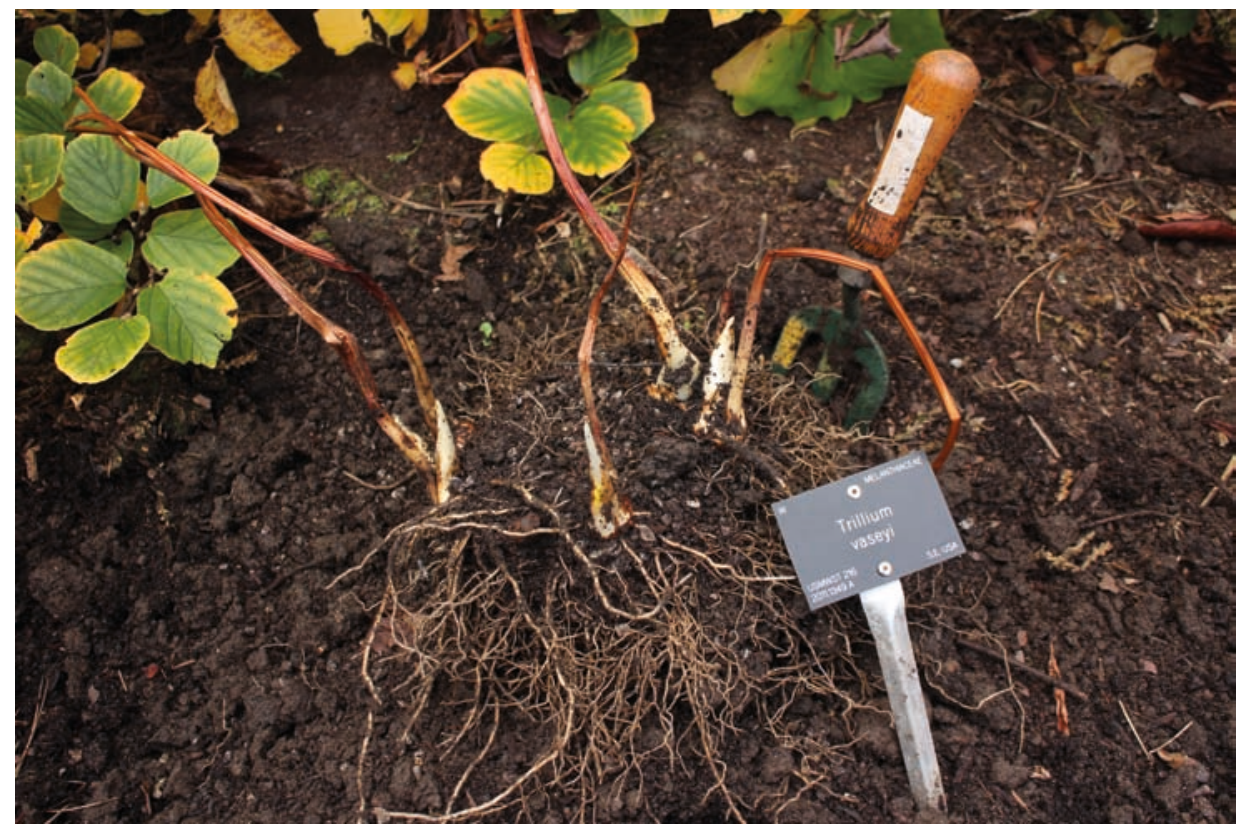

Fig. 7 After a season growing in the ground in the Lower Woodland area Trillium vaseyi was lifted and carefully divided, allowing the rhizomes more space to bulk up. Photo: Robert Unwin. 
space to grow. The rhizomes were very healthy indeed, had extensive root systems and have established and bulked up well.

\section{OTHER SPECIES COLLECTED}

While trilliums were the main target for the collecting trip they are only half of the story. North Carolina is one of the most species-diverse temperate areas of the world and is home to around 4,500 different species of plants. Away from the coastal areas many of these are suitable for cultivation in Scotland and our trip provided the perfect opportunity to collect some. In addition to over 50 trillium accessions, the USMWST trip returned with over 100 accessions of other herbaceous plants and ferns and a further 50 accessions of woody plants.

Associated with almost every trillium species was the beautiful Sanguinaria canadensis which also grows well in the Rock Garden at RBGE. Like the trilliums, this too was going dormant and with seed long since dispersed living samples were collected which are now thriving in the Lower Woodland. Another plant which is growing well in this area is Lilium superbum (Fig. 8), which flowered for the first time in 2013. Unfortunately we never saw the spectacular Lilium michauxii (Fig. 9) in sufficiently

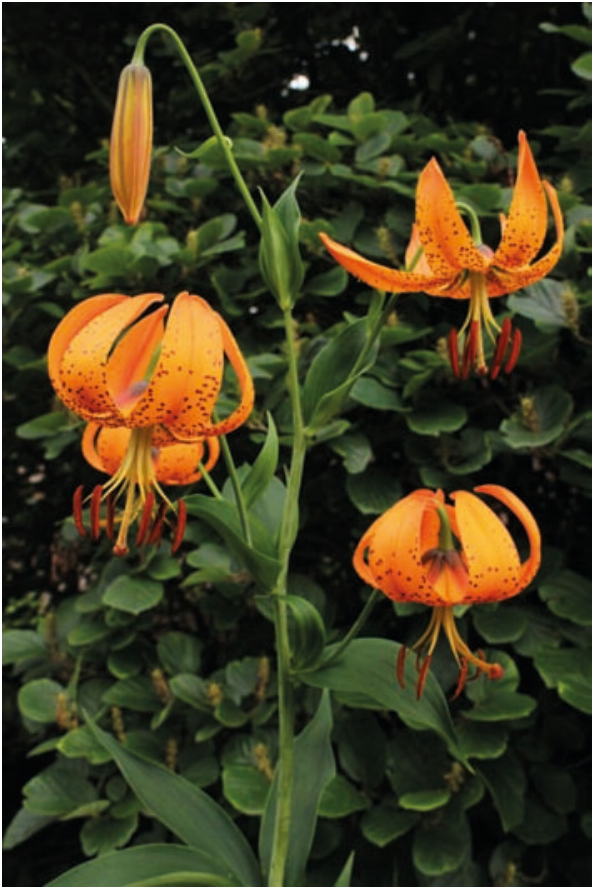

Fig. 8 Lilium superbum 20111411 collection on the field trip, flowering in cultivation in the Lower Woodland area at RBGE in 2013. Photo: Robert Unwin.

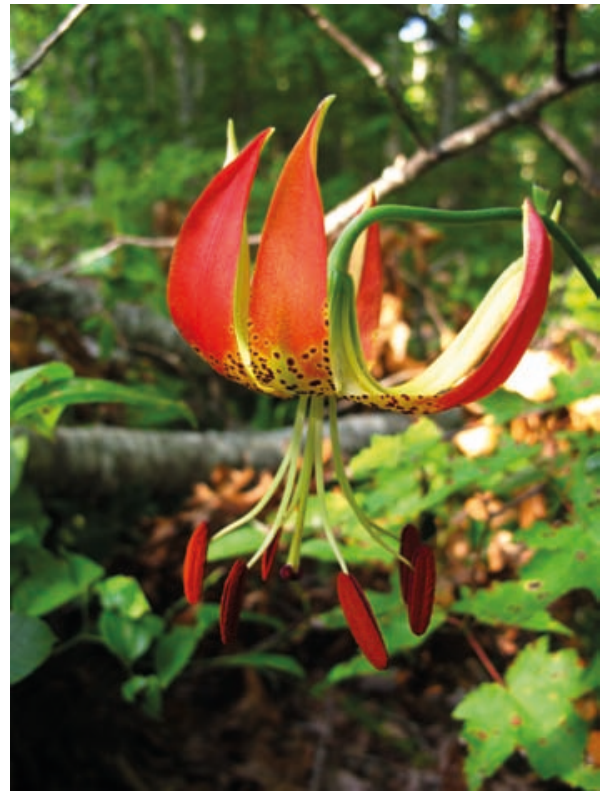

Fig. 9 Lilium michauxii flowering in its native woodland habitat in North Carolina. Photo: Robert Unwin. 
large populations in order to collect anything other than a herbarium specimen. The collections of Actaea pachypoda germinated well and were planted in the garden in spring 2012 where they have established quickly, flowering and berrying well in 2013. A list of species collected on the field trip is provided in Appendix 1.

Ferns are usually the first plants to germinate from a collection trip with results seen in only a few weeks. Consequently several species are already planted out in the Garden. Trees and shrubs take a little longer to appear in the Garden; however in the autumn of 2013 the first ones were planted in the Woodland Garden: Sorbus americana and Betula alleghaniensis. I am delighted that we have successfully germinated Magnolia fraseri from the seed collected and young trees are establishing well in the nursery at RBGE. This magnolia is a new species to the Living Collection. Magnolia species in general are notorious for producing only a small amount of viable seed which is reduced even further by parasites such as the assassin beetle in North Carolina. Another important collection was seed of Abies fraseri which unfortunately has germinated poorly in the nursery, although a small number survive. This is listed by the IUCN as endangered, largely due to populations being attacked by the balsam woolly adelgid (Adelges piceae). We also collected over 200 herbarium specimens alongside the seed and living collections, all of which are recorded in the database, mounted and homed in the Herbarium at RBGE.

\section{CONCLUSION}

The addition of the living material, and in particular trilliums, to the Living Collection has made a great contribution to the recently redeveloped Lower Woodland area at RBGE (see Unwin, 2013 for a description of this work). The germination results achieved with the trillium seed collected is an encouraging sign that in years to come larger numbers of these beautiful plants will further enhance the Lower Woodland area at RBGE. Recently RBGE has been approached by Plant Heritage to consider becoming a holder of a National Collection of Trilliums. This recently collected material will

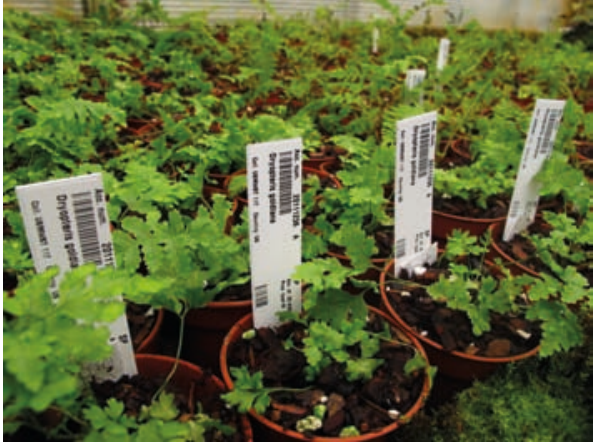

Fig. 10 Dryopteris goldiana was one of the first germinations from the USMWST collection trip. Photo: Robert Unwin.

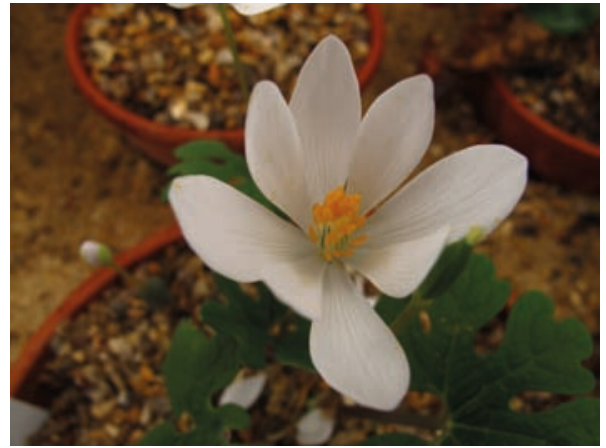

Fig. 11 Sanguinaria canadensis flowering in the Quarantine House prior to its release for planting out. Photo: Robert Unwin. 
be a valuable part of this National Collection. Should this idea come to fruition the opportunity for future collection trips targeting species which are not currently grown at RBGE will be carefully considered.

\section{REFERENCES}

CASE, F.W. JR \& CASE, R.B. (1997). Trilliums. Timber Press, Portland, OR.

RAE, D. (ed.), BAXTER, P., KNOTT, D., MITCHELL, D., PATTERSON, D. \& UNWIN, B. (2006). Collection Policy for the Living Collection. Royal Botanic Garden Edinburgh, Edinburgh.

RAE, D., CUBEY, R., GARDENER, G., LATTA, J. \& WALTER, K. (2006). Catalogue of Plants 2006. Royal Botanic Garden Edinburgh, Edinburgh.

MELLICHAMP, T.L. (2008). Sarracenia pitcher plants and bog gardening. Sibbaldia 6: 79-99.

UNWIN, R. (2013). The renovation of the Lower Woodland Garden at the Royal Botanic Garden Edinburgh. Sibbaldia 11: 97-108.

APPENDIX 1. LIST OF SEED AND LIVING MATERIAL COLLECTED UNDER ACRONYM USMWST

\section{Trilliums}

Trillium catesbaei

T. cuneatum

T. erectum

T. grandiflorum

T. luteum

T. rugelii

T. simile

T. sulcatum

T. undulatum

T. vaseyi

\section{Ferns}

Adiantum pedatum

Asplenium platyneuron

Athyrium asplenioides

Dennstaedtia punctilobula

Deparia sp.

D. thelypteroides

Dryopteris goldiana

D. marginalis

Polypodium appalachianum
Polystichum acrostichoides

Thelypteris noveboracensis

\section{Conifers}

Abies fraseri

Juniperus virginiana

Picea rubens

Pinus pungens

P. virginiana

Tsuga caroliniana

\section{Monocotyledons}

Allium cernuum

A. tricoccum

Amianthium muscitoxicum

Arisaema triphyllum

Carex fraseri

C. plantaginea

Clintonia borealis

C. umbellulata

Convallaria majuscula

Iris cristata 
I. verna

Lilium superbum

Maianthemum canadense

$M$. racemosum

Medeola virginiana

Melanthium parviflorum

Polygonatum biflorum

Prosartes lanuginosa

Tradescantia ohiensis

Uvularia perfoliata

U. puberula

U. sessilifolia

Xerophyllum asphodeloides

Veratrum maackii var. parviflorum

\section{Dicotyledons}

Acer saccharinum

Aconitum uncinatum

Actaea pachypoda

Aesculus flava

Alnus viridis ssp. crispa

Anemone sp.

Angelica triquinata

Aquilegia canadensis

Aristolochia macrophylla

Aronia melanocarpa

Aruncus dioicus

Asclepias exaltata

Asimina triloba

Astilbe sp.

Baptisia sp.

B. tinctoria

Betula alleghaniensis

Calycanthus floridus

Carpinus caroliniana

Carya sp.

Caulophyllum thalictroides

Ceanothus americanus

Chionanthus virginicus

Cimicifuga racemosa

Clematis viorna

Clethra acuminata
Coreopsis major

Cornus alternifolia

C. amomum

Corylus cornuta

Crataegus flabellata

C. punctata

C. succulenta

Diervilla sessilifolia

Diospyros virginiana

Diphylleia cymosa

Epigaea repens

Eryngium yиccifolium

Euonymus americanus

Eupatorium maculatum

Fagus grandifolia

Fothergilla major

Galax urceolata

Gaylussacia ursina

Gillenia trifoliata

Halesia tetraptera

Hamamelis virginiana

Hepatica acutiloba

H. americana

Heuchera villosa

Houstonia purpurea

Hydrangea arborescens

Hydrastis canadensis

Hylotelephium telephioides

Hypericum buckleii

Ilex montana

I. opaca

Itea virginica

Kalmia latifolia

Liatris spicata

Liquidambar styraciflua

Lonicera canadensis

Lyonia ligustrina

Magnolia acuminata

M. fraseri

M. macrophylla

M. tripetala

Melanthium parviflorum 
Menziesia pilosa

Monarda didyma

M. didyma hybrid

Nyssa sylvatica

Ostrya virginiana

Oxydendrum arboreum

Panax quinquefolius

Paronychia argyrocoma

Passiflora incarnata

Penstemon canescens

P. smallii

Penstemon sp.

Phemeranthus teretifolius

Phlox subulata

Physocarpus opulifolius

Phytolacca americana

Pieris floribunda

Podophyllum peltatum

Pycnanthemum montanum

Quercus prinus

Rhus copallinum

R. glabra

$R$. typhina

Ribes aureum var. villosum

Rosa carolina
Rubus odoratus

Salix humilis

Sambucus canadensis

Sassafras albidum

Saxifraga michauxii

Scutellaria incana

Sibbaldia tridentata

Silene stellata

S. virginica

Sorbus americana

Spiraea latifolia

Streptopus lanceolatus var. lanceolatus

Stuartia ovata

Thalictrum coriaceum

T. dasycarpum

T. revolutum

Trautvetteria caroliniensis

Uvaria grandifolia

Vaccinium alto-montanum

Vaccinium sp.

Viburnum cassinoides

V. lantanoides

Vitis rotundifolia

Xanthorhiza simplicissima 
